\title{
NEGATIVE AND POSITIVE EFFECTS OF TRAUMATIC EXPERIENCES IN A GROUP OF EMERGENCY SERVICE WORKERS - THE ROLE OF PERSONAL AND SOCIAL RESOURCES
}

\author{
NEGATYWNE I POZYTYWNE SKUTKI DOŚWIADCZEŃ TRAUMATYCZNYCH \\ U PRACOWNIKÓW SŁUŻB RATOWNICZYCH - ROLA ZASOBÓW OSOBISTYCH I SPOŁECZNYCH
}

University of Lodz / Uniwersytet Łódzki, Łódź, Poland

Department of Health Psychology / Zakład Psychologii Zdrowia

\begin{abstract}
Background: The purpose of the research is to investigate the role of personal (spirituality) and social (social support in the workplace) resources in both negative (post-traumatic stress disorder - PTSD symptoms) and positive (post-traumatic growth) effects of experienced trauma in a group of emergency service workers. Materials and Methods: Data of 116 workers representing emergency service (37.1\% firefighters, $37.1 \%$, police officers and $25.8 \%$ medical rescue workers) who have experienced traumatic events in their worksite were analyzed. The range of age of the participants was $21-57$ years $(\mathrm{M}=35.27 ; \mathrm{SD}=8.13)$. Polish versions of the Impact of Events Scale - Revised and the Post-traumatic Growth Inventory were used to assess the negative and positive effects of experienced events. Spirituality was assessed by self-report questionnaire and social support in the workplace scale was measured by the scale What support you can count on. Results: The results revealed that support from supervisors reduces the severity of PTSD symptoms, and spirituality and support from co-workers promote the growth after trauma. Conclusions: Personal resources in the form of spirituality, compared with the social resources, play more important role in gaining benefits from trauma than in protecting against the harmful effects of the experienced traumatic event. Med Pr 2013;64(4):463-472
\end{abstract}

Key words: PTSD symptoms, post-traumatic growth, spirituality, social support, emergency service workers

\section{STRESZCZENIE}

Wstęp: Celem podjętych badań było ustalenie roli zasobów osobistych (duchowość) i społecznych (wsparcie społeczne w pracy) w pojawianiu się negatywnych (objawy zespołu stresu pourazowego, post-traumatic stress disorder - PTSD) i pozytywnych (potraumatyczny wzrost) skutków doświadczeń traumatycznych w grupie pracowników służb ratowniczych. Materiał i metody: Analizie poddano wyniki badań 116 pracowników reprezentujących służby ratownicze, tj. strażaków (37,1\%), policjantów (37,1\%) i ratowników medycznych (25,8\%), którzy doświadczyli zdarzenia traumatycznego w związku z wykonywaną pracą. Wiek badanych wynosił 21-57 lat $(M=35,27 ; S D=8,13)$. Do oceny skutków doświadczanych zdarzeń wykorzystano polskie wersje Impact of Events Scale-R oraz Post-traumatic Growth Inventory. Duchowość oceniano za pomocą Kwestionariusza Samoopisu, przeznaczonego do pomiaru duchowości, a wsparcie społeczne w pracy mierzono skalą „Na jakie wsparcie możesz liczyć”. Wyniki: Uzyskane rezultaty ujawniły, że wsparcie pochodzące od przełożonych zmniejsza nasilenie objawów stresu pourazowego, a duchowość i wsparcie od współpracowników sprzyjają rozwojowi po traumie. Wnioski: Zasoby osobiste w postaci duchowości w porównaniu z zasobami społecznymi odgrywają większą rolę $\mathrm{w}$ procesie czerpania korzyści $\mathrm{z}$ traumy niż $\mathrm{w}$ ochronie przed negatywnymi skutkami doświadczanego zdarzenia traumatycznego. Med. Pr. 2013;64(4):463-472

Słowa kluczowe: objawy PTSD, potraumatyczny wzrost, duchowość, wsparcie społeczne, pracownicy służb ratowniczych

Corresponding author / Autorka do korespondencji: Nina Ogińska-Bulik, University of Lodz, Department of Health Psychology, Smugowa 10/12, 91-433 Łódź, Poland, e-mail: noginska@uni.lodz.pl

Received: 2013, July 22, accepted: 2013, August 28

\section{INTRODUCTION}

\section{Occurrence of traumatic events}

in emergency services and their consequences

Emergency service workers, particularly firefighters, medical rescue workers and police officers are exposed to experiencing traumatic events related to the nature of their job. The percent of people among emergency serv- ice representatives who experience such events oscillates from $3.6 \%$ to $75 \%$ (1). Firefighters are the group of workers who are most frequently exposed to such situations. According to the studies on the group of firefighters from rescue-firefighting units conducted by the Nofer Institute of Occupational Medicine in Łódź, 86\% of them experienced a traumatic event, and $78 \%$ experienced it more than once (2). The approximate results were noted in 
studies carried out by Ogińska-Bulik and Langer (3), as well as by Ogińska-Bulik and Kaflik-Pieróg (4).

High rate of traumatic event occurrence can also be identified in the group of police officers. Results of the studies conducted by the Nofer Institute of Occupational Medicine in Łódź (5) indicate that $57 \%$ of subjects experienced a traumatic event, whereas nearly $50 \%$ of them - more than once. Also, $72 \%$ of the members of emergency medical service units suffered from traumatic experiences concerned with their occupation.

Occurrence of a traumatic event entails a number of negative consequences among which one can distinguish post-traumatic stress disorder (PTSD). It is concerned with symptoms remaining for at least 1 month, which can be divided into the following three groups (5-7):

- Recurrence (intrusion) - which can be characterized by recurrence and re-suffering of the same experience, most notably in the form of memories and dreams;

Avoiding - resulting in reduced reactivity, avoiding stimuli, actions, feelings or talks related to trauma;

Psycho-physiological hyper-arousal - occurring in the form of difficulties with falling asleep, REM sleep, frequent awakenings, rapid tantrums, difficulties in staying concentrated, or increased watchfulness.

Polish studies show that post-traumatic stress disorder in our country refers to $10-16 \%$ of adults (8) and it is insignificantly lower regarding firefighters and police officers. Actual PTSD symptoms, which remain for at least one month, were noted among nearly $5 \%$ of firefighters (2) and $4 \%$ of police officers (5).

Within the last couple of years, researchers' attention has been also drawn to positive effects of trauma, appearing in the form of post-traumatic growth. Post-traumatic growth regards the occurrence of positive changes which encompass self-perception changes, changes with respect to relations with other people and appreciation of one's life, which can emerge as a consequence of attempting to deal with an experienced traumatic event (9).

Positive changes can result from various traumatic experiences, such as sudden death of one's relatives, exposure to warfare, being a victim of a road accident, diverse natural disasters (floods, fires, tornadoes), experiences regarding severe somatic disease or traumatic events concerned with one's profession. The review of studies related to it was presented in Ogińska-Bulik's work (10). Among the growth conditions subsequent to trauma, apart from factors related to the trauma itself (in particular its intensity), much emphasis is placed on the impact of personal and social resources, most notably social support.

\section{Social support, and negative and positive effects of traumatic experiences}

The importance of social support as a protection against negative effects of traumatic experiences was confirmed by a number of studies. Their review was depicted by, inter alia, Łuszczyńska (11), as well as Sęk and Cieślak (12). Yet, one does not have sufficient knowledge about the role of support as a factor increasing the likelihood of the occurrence of positive changes after experiencing a traumatic event. It seems to be of paramount importance in the process of the emergence of these changes.

Tedeschi and Calhoun $(9,13)$ and Harvey et al. $(14)$ highlight the significance of support for post-traumatic growth. The researchers emphasize that sharing one's emotions with other people is a key factor in the process of dealing with trauma, especially when one's family member passes away. Social support allows for expressing emotions, negative ones in particular, sharing them, as well as receiving practical assistance. It supports cognitive event processing and, therefore, is conducive to psychological trauma processing, and simultaneously increases chances of the occurrence of positive posttraumatic changes. Tedeschi and Calhoun (15) suggest that the importance of support is concerned with the fact that provided help mobilizes the processes of active rumination among traumatized people, which facilitates the occurrence of positive changes. Therefore, it is important to provide a network of support, including formal groups which can provide assistance to a person in need.

In the process of effective dealing with trauma which can result in the occurrence of positive changes, noticed social support plays a more crucial role than the presence of support, that is the fact that a person can notice people who are ready to provide help in critical situations. Quest for support, both instrumental and emotional, is primarily associated with noticing new possibilities in one's life and improved relations with others. Moreover, the source of support appears to be equally vital for post-traumatic growth. When it comes to experiencing traumatic events, being a consequence of performed work, supervisors' and co-workers' support (12) seems to be essential.

\section{Spirituality, and negative and positive effects of traumatic experiences}

Spirituality is understood in a variety of ways, depending on a discipline or philosophical assumptions. Heszen $(16,17)$ points out two major trends of construing spirituality. The first one links this term to religion. Another one assumes that spirituality and religiousness, 
even though related, are separate constructs. Spirituality is referred to individual and personal experience, whereas religion is treated as a social and institutionalized phenomenon. Irrespectively of spirituality presentation, one stresses that it is a complex and multi-dimensional construct.

The essence of spirituality, considered from the psychological point of view, is transcendence understood as going beyond reality, cognition which goes beyond the scope of experience. The category of spirituality is therefore related to God, Force Majeure, Mind as values which provide human's life with meaning and goals. Spirituality perceived as a resource (unit's attribute) is ascribed to - following other theoretical constructs regulatory value in relation to the defined scope of man's activity, which is also underlined by Juczyński (18). It means that spirituality, considered a human resource, aims to explain specific activity of transcendence.

The available empirical material provides numerous pieces of evidence that there is a dependency between spirituality and people's health. This relation results in, among others, development of spirituality among persons who deal with critical situations, e.g. chronic somatic diseases. Studies with respect to influence of spirituality on adjustment to disease or the course of treatment or rehabilitation are also conducted. Spirituality turned out to be a factor which reduces intensity of fear and depression symptoms among oncologic patients and people addicted to alcohol (19). It was also proved that spirituality can protect against development of post-traumatic stress symptoms or reduce their intensity. Negative dependencies between spirituality and intensification of PTSD symptoms were obtained, inter alia, in the studies on Afro-Americans who experienced violence at home (20) or victims of sexual offences (21).

Spirituality/religiousness is also fundamental for the occurrence of positive changes after experiencing traumatic event. The results of the studies conducted on a group of young adults confirm it; as well as positive relation between religiousness, expressed mainly in the form of participation in religious activities, and posttraumatic growth (22). A similar relation was observed within Park's and Fenster's research (23). The importance of spirituality/religiousness for the development of positive changes after traumatic event is also confirmed by meta-analyses of study results $(24,25)$.

An indirect evidence for existence of dependency between spirituality and occurrence of positive posttraumatic changes are results of studies conducted on a group of people who lost somebody close, which in- dicate a positive relation of post-traumatic growth and no dynamics, that is spiritual dynamics and coherence, particularly the sense of meaningfulness (26) and perception of sense of life (10).

It has to be highlighted that majority of studies concerning dependency between spirituality and post-traumatic growth regarded dealing with a chronic somatic disease. So far, no studies of this type, among workers experiencing traumatic events related to their profession, have been conducted.

\section{MATERIAL AND METHODS}

The goal of undertaken studies was to establish the role that personal (spirituality) and social (social support) resources play in the occurrence of effects (negative and positive) of experienced traumatic events among emergency service workers. Post-traumatic stress symptoms accounted for the indicator of negative consequences, whereas post-traumatic growth for positive effects.

The following research questions were posed:

Do, and to what extent, symptoms of post-traumatic stress among emergency service workers occur?

Are there any, and what kind of, positive changes after trauma perceived by the studied workers?

Do age and one's profession have an impact on the rate of negative and positive effects of traumatic experiences?

Are spirituality and perceived social support in the worksite concerned with intensification of PTSD symptoms and post-traumatic growth?

What dimensions does spirituality consist of and what sources of support allow to anticipate post-traumatic stress symptoms and post-traumatic growth?

200 employees (men only), representing emergency services from Podkarpacie, Warszawa and Łódź ${ }^{1}$ accounted for the subject group. The study was conducted subsequent to supervisors' and studied subjects' consents. The studied persons were informed of the goal of the study and its anonymity. Prior to filling in questionnaires, subjects answered (in writing) questions regarding whether they had experienced a traumatic event related to their profession. 116 representatives of emergency service admitted experiencing such a situation. This group, which accounted for $58 \%$ of all of the studied persons, was the subject of our further analyses. It included 43 firefighters (37.1\%), 43 Prevention Department police officers (37.1\%), and 30 medical res-

\footnotetext{
${ }^{1}$ Studies were conducted by the member of MA seminar - Bartłomiej Dziuba.
} 
cue workers (25.8\%). Subjects aged 21-57 $(\mathrm{M}=35.28$; $\mathrm{SD}=8.13$ ) participated in the study.

In order to assess negative effects of experienced traumatic events, Impact of Events Scale was used, for the positive - Post-traumatic Growth Inventory. The measurement of spirituality was performed by means of Experiences Questionnaire, while the assessment of social support via the scale of "What support you can count on".

The Impact of Events Scale is a Polish adaptation of the revised version of the Impact of Events Scale (IES) by Weiss and Marmar (27), devised by Juczyński and Ogińska-Bulik (7). It contains 22 statements (e.g. "As soon as I recalled this event, emotions came back") and considers three PTSD dimensions: 1) intrusion, which expresses returning pictures, dreams, thoughts or perceptional emotions related to trauma; 2) arousal, which is characterized by intense watchfulness, fear, impatience, difficulties in staying concentrated, and 3) avoiding - resulting in efforts to get rid of thoughts, emotions or conversations related to trauma. According to instructions, a studied person describes the negative event in the first place (in this case, it was an event related to one's profession), which is followed by the assessment of symptoms using Likert's 5-degree scale (0-4). The scale serves to establish current and subjective discomfort related to a specific event. This tool is known for good psychometric parameters.

Post-traumatic Growth Inventory, created by Tedeschi and Calhoun (9), was adapted to Polish conditions by Ogińska-Bulik and Juczyński (28). The tool consists of 21 statements which describe various positive changes resulting from the experienced traumatic events (e.g. "I've changed my priorities regarding what is important in my life"), toward which a studied person takes an attitude via selecting the following answers: from "I haven't experienced this change" (0 points) to "I have experienced this change to a great extent" (5 points). The higher the number of points, the more significant the intensification of positive changes. In the Polish version, the inventory measures 4 factors accounting for post-traumatic growth. These are the following: changes in self-perception, changes with respect to relations with other people, increased appreciation of life and spiritual changes. The overall result is a sum of the aforementioned four factors. The tool has got satisfactory psychometric properties. Cronbach's alfa indicator equals 0.93 (for particular factors from 0.63 to 0.87 ) and is slightly higher than in the case of the original version.

In order to measure spirituality, the Self-description Questionnaire devised by Metlak, Heszen-Niejodek,
Gruszczyńska (29) was used. The questionnaire consists of 20 questions (e.g. "Faith in God allows me to survive difficult situations in my life") with a 5 -point scale of answers ( 1 - strongly disagree, 5 - strongly agree). The questionnaire checks 3 aspects of spirituality:

religiousness (7 items) - the level of using religious practices in everyday life,

ethical sensitivity ( 7 items) - referring to the level of ethical attitude,

harmony (6 items) - expressing the sense of belonging to the world, perceiving it as friendly, a sense of internal peace and joy. The higher the score, the higher the level of spirituality.

The questionnaire has satisfactory psychometric properties.

In order to assess the perceived social suport, the "What support you can count on" scale, developed by Cieślak (30) was applied. It is a shortened version of the previous Social Support Scale. The tool consists of 16 statements concerning the perceived social suport when working. Eight items refer to the supervisors' support (e.g. "To what extent you can count on your supervisors with respect to their help in a certain way") and also 8 - co-workers' support (e.g. “To what extent you can count on your co-workers with respect to their help in a certain way"). Regarding each statement, a studied person expresses his/her opinion via the scale from 1 (inconsiderable extent) to 5 (to a great extent). The psychometric indicators of the scale shall be considered satisfactory.

\section{FINDINGS}

Having checked the normality of the arrangement of analyzed variables, their mean values, jointly with standard variations, were established. With reference to negative and positive effects of experienced traumatic events, the age of subjects and their professions were taken into account. In another stage, the dependencies between variables were fixed using Pearson's correlation coefficients and it was checked which of the spirituality factors and which sources of social support (independent variables) play a predictive role with regard to post-traumatic stress symptoms and post-traumatic growth, treated as dependent variables.

\section{Negative and positive effects of experienced traumatic events}

The obtained mean values of symptoms, which account for the post-traumatic stress disorder (Table 1), do not substantially depart from the results of normalization studies (7). Considering the criterion of 1.5 point as the 
limit value to PTSD, 71 persons, which accounts for $61.2 \%$ of the studied persons, reveal at least moderate, whereas 45 persons (38.8\%) indicate their inconsiderable intensification.

Age does not diversify the general result of the Impact of Event Scale: younger aged, below $35(\mathrm{~N}=67)-$ $\mathrm{M}=37.28$ ( $\mathrm{SD}=18.64$ ); older aged, 35 and more $(\mathrm{N}=49)-\mathrm{M}=39.73$ ( $\mathrm{SD}=19.8)$; or any of its components. Subjects' professions also do not result in intensified PTSD symptoms. The conducted analysis of variations of the general result of the Impact of Event Scale did not indicate any differences between mean values $(\mathrm{F}=1.95)$ : firefighters $-\mathrm{M}=33.93(\mathrm{SD}=18.82)$, police officers $-\mathrm{M}=39.97$ ( $\mathrm{SD}=22.05)$, medical rescue workers $-\mathrm{M}=42.23$ ( $\mathrm{SD}=13.44)$. However, significant differences in terms of avoiding $(\mathrm{F}=3.15 ; \mathrm{p}<0.05)$ were detected. A considerably higher intensification of avoiding was observed among medical rescue workers $(\mathrm{M}=14.17 ; \mathrm{SD}=4.33)$ when compared to firefighters $(\mathrm{M}=10.53 ; \mathrm{SD}=5.84)(\mathrm{p}<0.05)$.

The average value of post-traumatic growth (Table 1 ) corresponds with 5 of the standard ten; it is then an average result. The mean values in Post-traumatic Growth Inventory obtained by emergency service workers do not significantly differ from the results obtained in normalization studies (28). 46 (39.7\%) of the studied indicate a low, $40(34.5 \%)$ - average and $30(25.8 \%)$ - high level of post-traumatic growth. No substantial differences in terms of the level of particular post-traumatic growth factors were noted, whose mean values (obtained subsequent to dividing results by the number of corresponding statements) are as follows: factor 1 - changes in self-perception $-M=2.63$,

factor 2 - changes in relations to others people $\mathrm{M}=2.60$,

factor 3 - appreciation of life $-\mathrm{M}=3.13$,

factor 4 - spiritual changes $-\mathrm{M}=2.42$.

It means that subjects represent a similar level of changes regarding all of the four analyzed areas accounting for post-traumatic growth.

Subjects' age does not diversify intensification of posttraumatic growth. The mean value for younger workers (aged below 35) equals $55.98(\mathrm{SD}=21.331)$ and does not significantly differ in terms of statistics $(t=-0.09)$ from the mean value obtained by older workers (aged 35 onwards): $\mathrm{M}=56.37$ ( $\mathrm{SD}=23.78)$. No differences in particular dimensions of post-traumatic growth were recorded.

It was also checked if one's profession (firefighter, police officer, medical rescue worker) was related to the level of post-traumatic growth. The studied persons, regardless of their occupation, represent a similar level of positive changes subsequent to experiencing traumatic events $(\mathrm{F}=1.06)$ - firefighters: $\mathrm{M}=59.84(\mathrm{SD}=17.42)$, police officers: $\mathrm{M}=53.46(\mathrm{SD}=24.42)$, medical rescue workers: $\mathrm{M}=54.70$ ( $\mathrm{SD}=21.31)$. No significant statistical differences in terms of the intensification of particular post-traumatic growth factors were observed.

The obtained mean values for the measurement of spirituality equal as follows: for the general indicator $\mathrm{M}=72.18(\mathrm{SD}=12.97)$, religiousness $-\mathrm{M}=24.92$ ( $S D=6.38)$, ethical values $-M=26.70(S D=4.79)$, harmony $-\mathrm{M}=20.55$ ( $\mathrm{SD}=4.48$ ). In the case of social support: for supervisors' support $-\mathrm{M}=22.31(\mathrm{SD}=7.54)$, co-workers' support $-\mathrm{M}=26.56(\mathrm{SD}=7.25)$.

Table 1. Mean values of post-traumatic stress disorder symptoms and post-traumatic growth Tabela 1. Średnie wartości objawów zespołu stresu pourazowego i potraumatycznego wzrostu

\begin{tabular}{|c|c|c|c|c|}
\hline $\begin{array}{l}\text { Variables } \\
\text { Zmienne }\end{array}$ & M & SD & $\begin{array}{l}\text { Min } \\
\text { Min. }\end{array}$ & $\begin{array}{c}\text { Max } \\
\text { Maks. }\end{array}$ \\
\hline PTSD symptoms - total / Objawy stresu pourazowego - ogółem & 38.31 & 19.09 & 0 & 78 \\
\hline 2. Hyperarousal / Pobudzenie & 11.69 & 6.77 & 0 & 28 \\
\hline 3. Avoidance / Unikanie & 12.16 & 6.24 & 0 & 26 \\
\hline factor 1. Changes in self-perception / czynnik 1. Zmiany w percepcji siebie & 23.75 & 9.23 & 0 & 43 \\
\hline factor 2. Changes in relations to others / czynnik 2. Zmiany w relacjach $\mathrm{z}$ innymi & 18.21 & 8.44 & 0 & 35 \\
\hline factor 3. Appreciation of life / czynnik 3. Docenianie życia & 9.34 & 3.94 & 0 & 20 \\
\hline factor 4. Spiritual changes / czynnik 4. Zmiany duchowe & 4.84 & 2.81 & 0 & 10 \\
\hline
\end{tabular}

M - mean / średnia; SD - standard deviation / odchylenie standardowe.

Min - minimum value / Min. - wartość minimalna; Max - maximum value / Maks. - wartość maksymalna. 


\section{Relations between spirituality and social support, and negative and positive effects of traumatic experiences}

Relations between spirituality and social support, and negative and positive effects of traumatic events were established by means of correlation coefficients shown in Tables 2 and 3.

Correlation coefficients shown in Table 2 indicate lack of relation to spirituality and weak dependency of social support with post-traumatic stress symptoms. Only supervisors' support correlates - negatively - with PTSD symptoms, that is a general result of the Impact of Events Scale and its two dimensions, i.e. intrusion and avoiding, yet the correlations are weak. The greater the support, the weaker the intensification of symptoms (Table 3).

The obtained results suggest that there is a statistically significant positive relation between spirituality and post-traumatic growth. It concerns all of the dimensions creating the Post-traumatic Growth Inventory. Changes with respect to spiritual sphere, which seems to be understandable, have the strongest correlation with spirituality. A relatively strong relation also concerns changes with regard to relations with other people, weaker, in turn, changes in respect of self-perception and appreciation of life. Among particular dimensions, which account for spirituality, harmony and religiousness turned out to have the strongest relations with post-traumatic growth.

Among the two analyzed sources of social support, only co-workers' support positively correlates with posttraumatic growth. Significant relations concern both the general level of growth and almost all of the factors (except for appreciation of life) accounting for the Post-traumatic Growth Inventory. Social support received from co-workers has stronger relations with changes with respect to self-perception and relations with other people than changes regarding the spiritual sphere.

Table 2. Correlation coefficients between spirituality, social support and post-traumatic stress disorder (PTSD) symptoms Tabela 2. Współczynniki korelacji między duchowością, wsparciem społecznym a objawami zespołu stresu pourazowego (PTSD)

\begin{tabular}{|c|c|c|c|c|}
\hline $\begin{array}{l}\text { Variables } \\
\text { Zmienne }\end{array}$ & $\begin{array}{l}\text { PTSD (total) } \\
\text { PTSD (ogółem) }\end{array}$ & $\begin{array}{l}\text { Intrusion } \\
\text { Intruzja }\end{array}$ & $\begin{array}{l}\text { Hyperarousal } \\
\text { Pobudzenie }\end{array}$ & $\begin{array}{l}\text { Avoidance } \\
\text { Unikanie }\end{array}$ \\
\hline Spirituality - total / Duchowość - ogółem & 0.01 & -0.05 & 0.01 & -0.03 \\
\hline Ethical sensitivity / Wrażliwość etyczna & -0.03 & -0.01 & 0.02 & -0.01 \\
\hline Harmony / Harmonia & -0.08 & -0.05 & -0.07 & -0.07 \\
\hline Support from co-workers / Wsparcie od współpracowników & -0.10 & -0.10 & -0.02 & -0.08 \\
\hline
\end{tabular}

${ }^{*} \mathrm{p}<0.05$.

Table 3. Correlation coefficients between spirituality, social support and post-traumatic growth

Tabela 3. Współczynniki korelacji między duchowością, wsparciem społecznym a potraumatycznym wzrostem

\begin{tabular}{|c|c|c|c|c|c|}
\hline \multirow{2}{*}{$\begin{array}{l}\text { Variables } \\
\text { Zmienne }\end{array}$} & \multirow{2}{*}{$\begin{array}{l}\text { PTGI } \\
\text { IPR }\end{array}$} & \multicolumn{4}{|c|}{$\begin{array}{c}\text { Factor } \\
\text { Czynnik }\end{array}$} \\
\hline & & 1 & 2 & 3 & 4 \\
\hline Spirituality - total / Duchowość - ogółem & $0.40^{* * *}$ & $0.26^{* *}$ & $0.45^{* * *}$ & $0.22^{*}$ & $0.54^{* * *}$ \\
\hline Religiousness / Religijność & $0.35^{\star * *}$ & $0.20^{*}$ & $0.40^{* * *}$ & $0.20^{*}$ & $0.55^{* * *}$ \\
\hline Ethical sensitivity / Wrażliwość etyczna & $0.23^{*}$ & 0.15 & $0.25^{\star *}$ & 0.12 & $0.29^{* *}$ \\
\hline Harmony / Harmonia & $0.41^{* * *}$ & $0.30^{* * *}$ & $0.46^{* * *}$ & $0.22^{*}$ & $0.45^{* * *}$ \\
\hline Support from supervisors / Wsparcie od przełożonych & 0.14 & 0.17 & 0.14 & -0.07 & $0.19^{*}$ \\
\hline Support from co-workers / Wsparcie od współpracowników & $0.30^{* *}$ & $0.30^{* *}$ & $0.32^{* *}$ & 0.11 & $0.19^{*}$ \\
\hline
\end{tabular}

${ }^{* * *} \mathrm{p}<0.001 ;{ }^{* *} \mathrm{p}<0.01,{ }^{*} \mathrm{p}<0.05$.

PTGI - general score of Post-traumatic Growth Inventory / IPR - wynik ogólny Inwentarza Potraumatycznego Rozwoju.

1 - Changes in self-perception / Zmiany w percepcji siebie; 2 - Changes in relations to others / Zmiany w relacjach z innymi; 3 - Appreciation of life / Docenianie życia;

4 - Spiritual changes / Zmiany duchowe. 
Regarding another stage, it was aimed to find an answer to the question of which of the analyzed resources (spirituality or support) plays a more important role in anticipating negative and positive effects of experienced traumatic events. In order to do so, the analysis of regression (forward stepwise) was applied. As independent variable, particular dimensions of spirituality and both sources of support were considered. The final comparison of the obtained results was shown in Tables 4 and 5.

Only the supervisors' support turned out be a predictor of PTSD symptoms (general score) perceived as a negative effect of experienced traumatic events in the studied group of emergency service workers. However, its impact on the anticipation of these symptoms equals $5 \%$. A more detailed analysis indicated that this type of support plays a predictive role with regard to intrusion $\left(\beta=-0.22 ; R^{2}=0.06\right)$ and arousal $\left(\beta=-0.24 ; R^{2}=0.06\right)$. The greater the supervisors' support, the less suffering from the post-traumatic stress, particularly regarding intrusion and arousal. No predictors of post-traumatic stress symptoms, that is avoiding, were found.

Two dimensions constituting spirituality, i.e. harmony and religiousness, as well as co-workers' support turned out to be the predicators of post-traumatic growth in the studied group of emergency service workers. Harmony has the greatest impact, which explains $18 \%$ of dependent variable. Other two variables explain the minor percent of variability, i.e. social support - 5\%, and religiousness $-3 \%$.

Being in quest of predictors of particular dimensions of post-traumatic growth, it was established that harmony and co-workers' support allow also to predict positive changes regarding self-perception. Harmony $(\beta=0.23)$ explains $9 \%$ of variances, whereas co-workers' support $(\beta=0.22)$ - solely $4 \%$.

Three variables were predictors of positive changes in relations with other people, i.e. harmony $(\beta=0.38)$, whose participation in the anticipation of these changes is most considerable (equals $21 \%$ ), religiousness $(\beta=0.30)$, which explains $4 \%$ and co-workers' support $(\beta=0.26)$, which allows to predict changes solely in $2 \%$.

Increased appreciation of life, in turn, is explained (negatively) by supervisors' support $(\beta=-0.26)$ and harmony $(\beta=0.19)$. The impact of both variables is not significant; they explain solely $5 \%$ of the dependent variable.

Two factors accounting for spirituality are predictors of positive changes in the spiritual sphere, i.e. religiousness $(\beta=0.45$ ), which explains $28 \%$ and harmony $(\beta=0.29)$ explaining $6 \%$ of the dependent variable.

Table 4. Predictors of post-traumatic stress disorder symptoms

Table 4. Predyktory objawów zespołu stresu pourazowego

\begin{tabular}{lcccc}
\hline \multicolumn{1}{c}{$\begin{array}{l}\text { Variables } \\
\text { Zmienne }\end{array}$} & $\beta$ & Std. error of B & Błąd B & p \\
\hline Support from supervisors / Wsparcie od przełożonych & -0.19 & -0.47 & 0.24 & -2.01 \\
Constant / Wartość stała & - & 48.72 & 5.48 & 8.87 \\
\hline
\end{tabular}

$\mathrm{R}=0.19 ; \mathrm{R}^{2}=0.05$

$\beta$ - standardized regression coefficient / standaryzowany współczynnik regresji.

$\mathrm{B}$ - non-standardized regression coefficient / niestandaryzowany współczynnik regresji.

$\mathrm{t}$ - test $\mathrm{t}$ value / wartość testu $\mathrm{t}$.

$\mathrm{p}$ - level of significance / poziom istotności.

$\mathrm{R}$ - correlation coefficient / współczynnik korelacji.

$\mathrm{R}^{2}$ - coefficient of determination / współczynnik determinacji.

Table 5. Predictors of post-traumatic growth

Tabela 5. Predyktory potraumatycznego wzrostu

\begin{tabular}{|c|c|c|c|c|c|}
\hline $\begin{array}{l}\text { Variables } \\
\text { Zmienne }\end{array}$ & $\beta$ & B & $\begin{array}{c}\text { Std. error of B } \\
\text { Błąd B }\end{array}$ & $\mathrm{t}$ & $\mathrm{p}$ \\
\hline Harmony / Harmonia & 0.34 & 1.60 & 0.49 & 3.22 & 0.001 \\
\hline Religiousness / Religijność & 0.25 & 0.86 & 0.34 & 2.48 & 0.020 \\
\hline Constant / Wartość stała & - & 9.41 & 10.80 & 0.87 & ns \\
\hline
\end{tabular}

$\mathrm{R}=0.50 ; \mathrm{R}^{2}=0.26$, ns - non significant / nieistotne statystycznie.

Abbreviations as in Table 4 / Objaśnienia jak w tabeli 4. 


\section{SUMMARY AND CONCLUSIONS}

A high percent of the studied representatives of emergency service workers (61.2\%) applies to at least moderate intensification of post-traumatic stress symptoms, whereas $38.8 \%$ indicate their low level, which suggests a considerable stress-inducing nature of one's profession. Taking into consideration positive effects of experiences traumatic events, it has to be indicated that nearly $40 \%$ of subjects apply to low level of post-traumatic growth (34.5\% - average, and 25.8\% - high).

Spirituality and co-workers' support turned out to be associated with positive effects of the experienced traumatic events, while supervisors' support with negative ones. It is worth emphasizing that none of the dimensions creating spirituality allows to predict PTSD symptoms. It suggests that spirituality, treated as human's subject feature, plays a slightly different role with relation to other personal and social resources of man. It does not protect against negative effects of trauma, whose intensification, in the form of PTSD symptoms in the studied group of representatives of emergency service workers, turned out to be high. It can be related to the type of the experienced events for which workers are (or at least should be) prepared. As a rule, these situations are controlled.

One can understand that representatives of emergency service workers, dealing with traumatic events, undertake mostly active strategies of managing, aiming at dealing with a particular situation (rather than escaping stress via reference to God, religion etc.). Supposedly, they also make use of other personal resources. Regarding traumatic experiences occurring in the worksites of representatives of emergency service workers, a considerably greater importance is assigned to such resources as the sense of coherence or perceiving one's effectiveness $(5,31)$.

Lack of relationship between spirituality and occurrence of PTSD symptoms can be linked to the sex of men, when compared to women, as they less frequently use resources like spirituality and more seldom refer to religion as a method of dealing with stress (16). It is worth paying attention to the reasonableness of distinguishing spirituality and religiousness, which are frequently used interchangeably, particularly because the available data indicates an ambiguous relation between them and negative consequences of trauma. It is supported by the studies conducted by McIntosh et al. (32) which proved that religiousness was the predictor of weaker symptoms of intrusion, whereas spirituality - stronger.
Attention is also paid to the occurrence of the socalled negative spirituality or negative religious managing. This type of spirituality is associated with dissatisfaction with God, assigning fault to God, or responsibility for the experienced event, as well as sensing punishment for sins. Such spirituality can facilitate maintenance of PTSD symptoms. It is proved by the suited of Wortmann et al. (33) which showed that spiritual struggle, referring to negative convictions concerned with God, was positively associated with the intensified PTSD symptoms.

Spirituality refers positively to all of the dimensions of post-traumatic growth, and the strongest - which seems reasonable - with positive changes in spiritual sphere, and the weakest - with appreciation of life. Among the elements of spirituality, the most essential role should be assigned to harmony, more inconsiderable to religiousness. Harmony, which expresses the feeling of internal peace and joy, belonging to the world and perceiving it as friendly, allows to anticipate the occurrence of positive changes in all of the post-traumatic growth areas, to the greatest extent in the spiritual sphere and in relations with other people. Religiousness is of similar importance - yet weaker - which has the tendency to undertake religious practices in everyday life, which facilitates primarily all of the positive changes in spiritual sphere.

Positive relations between spirituality and post-traumatic growth, which is treated as the effect of successful dealing with trauma, may result from its impact on the undertaken strategies of dealing with stress. The results of studies quoted by Heszen (16) confirm the occurrence of positive relation between spirituality and adaptive coping strategies and negative - yet weaker - with reference to less adaptive coping strategies.

Spirituality seems also to facilitate dealing concentrated on meaning. This form of coping is considered a basic source of positive emotions, which can co-accompany stressful situations. It is important to add that spirituality/religiousness is also associated with other personal resources of man, which are activated in the situation of crisis, mostly with hope or optimism, which can additionally facilitate growth changes.

The obtained results of the studies show a different role of sources of perceived social support occurring in the worksite for negative and positive effects of experienced traumatic events. Supervisors' support is negatively related to post-traumatic stress symptoms, where as co-workers' support is positively associated with post-traumatic growth. Stronger dependencies were noted with references to growth. It means that supervisors' support serves as a buffer and mitigates the intensifica- 
tion of post-traumatic stress symptoms, above all, regarding intrusion and arousal. Co-workers' support, in turn, plays a role of promoting health and facilitates the occurrence of positive growth changes, mostly with respect to self-perception and relations with other people.

It has to be underscored that the obtained dependencies are weak. Perhaps, those who experience trauma do not find the very support important but they are mostly influenced by satisfaction from the received social support, which was not analyzed in the undertaken studies. Furthermore, it is also vital to highlight studies which did not confirm the importance of social support with reference to post-traumatic growth. Social support was not related to post-traumatic growth among cardiology patients (34), oncology patients (35) or among the sick with HIV, those who experienced trauma with regard to the Katrina hurricane in the United States (36). With respect to the recent studies, support correlated positively solely with one factor of Post-traumatic Growth Inventory, i.e. relations with other people. Researchers endeavor to explain this lack of dependencies with the fact that the role of support was established only with respect to the last 2 months preceding the study. It can suggest that the support plays a crucial role only for delayed effects of growth.

The conducted studies are concerned with certain restrictions. Evaluation of negative and positive effects of the experienced traumatic events were performed by means of self-description. The impact of variable social approval, i.e. willingness to present oneself in a positive light, in particular with reference to posttraumatic growth cannot be excluded. In the case of negative effects of the experienced traumatic events, only post-traumatic stress symptoms were studied; it was not a clinical diagnosis of PTSD. The studies did not include any analysis of the kind of experienced traumatic event. Plus, no period of time was considered.

Additionally, the studies were cross-sectional, which does not allow for stating the occurrence of cause-andeffect links. It is particularly concerned with spirituality. Therefore, it cannot be unequivocally stated that it is spirituality that facilitates positive post-traumatic changes. Also, a reverse impact is possible, i.e. the fact that dealing with traumatic experiences, emerging in the form of post-traumatic growth, increases the level of spirituality.

The possibility of the occurrence of common source of variance of spirituality and post-traumatic growth has to be considered (one of post-traumatic growth dimensions is positive change with respect to spirituality). Despite the aforementioned limitations, the importance of conducted research and obtained results has to be emphasized. They apply to the more and more popular trend, that is positive psychology, which focuses on the "strong" side of man. They implement novelties in the area of issues concerning the effects of experienced traumatic events, and can be used in practice.

\section{REFERENCES}

1. Pużyński S, Rybakowski J, Wciórka J. [Psychiatry. Vol 2: Clinical Psychiatry]. Wrocław: Urban \& Partner; 2011. Polish.

2. Koniarek J, Dudek B. [Post-traumatic stress disorder and a firefighters' attitude towards work]. Med Pr. 2001;52(3): 177-83. Polish.

3. Ogińska-Bulik N, Langer I. [Type D personality and strategies of dealing with stress, and intensification of PTSD symptoms in the group of firefighters]. Med Pr. 2007;58(4): 307-16. Polish.

4. Ogińska-Bulik N, Kaflik-Pieróg M. [Occurrence of positive changes among firefighters who experience traumatic events regarding their profession - the role of mental resilience]. Przedsiebiorcz Zarzadz. 2013;14:193-206. Polish.

5. Dudek B. [Traumatic stress disorder]. Gdańsk: Gdańskie Wydawnictwo Psychologiczne; 2003. Polish.

6. Lis-Turlejska M. [Traumatic events - ways of defining, measurement and dissemination]. In: Strelau J, Zawadzki B, Kaczmarek M, editors. [Mental consequences of trauma. Conditionings and therapy]. Warszawa: Wydawnictwo Naukowe Scholar; 2009. p. 15-33. Polish.

7. Juczyński Z, Ogińska-Bulik N. [Measurement of post-traumatic stress disorder - Polish version of revised Impact of Events Scale]. Psychiatria. 2009:6(1):15-25. Polish.

8. Lis-Turlejska M. [Traumatic stress. Occurrence, consequences, therapy]. Warszawa: Wydawnictwo Akademickie Żak; 2002. Polish.

9. Tedeschi RG, Calhoun LG. The Post-Traumatic Growth Inventory: Measuring the positive legacy of trauma. J Trauma Stress. 1996;9(3):455-71, http://dx.doi.org/10.1002/ jts.2490090305.

10. Ogińska-Bulik N. [Positive effects of traumatic experiences, that is when tears turn into pearls]. Warszawa: Wydawnictwo Difin; 2013. Polish.

11. Łuszczyńska A. [Social support and traumatic stress]. In: Sęk H, Cieślak R, editors. [Social support, stress and health]. Warszawa: Wydawnictwo Naukowe PWN; 2004. p. 190-204. Polish.

12. Sęk H, Cieślak R. [Social support - ways of defining, types and sources of support, selected theoretical conceptions]. In: Sęk H, Cieślak R, editors. [Social support, stress and health]. Warszawa: Wydawnictwo Naukowe PWN; 2004. p. 11-28. Polish. 
13. Tedeschi RG, Calhoun LG. [Clinic approach to the growth after post-traumatic experiences]. In: Linley PA, Joseph S, editors. [Positive psychology in practice]. Warszawa: Wydawnictwo Naukowe PWN; 2007. p. 230-48. Polish.

14. Harvey J, Barnett K, Overstreet A. Trauma growth and other outcomes attendant to loss. Psychol Inq. 2004;15(1):26-9.

15. Tedeschi RG, Calhoun LG. Posttraumatic growth: Conceptual foundations and empirical evidence. Psychol Inq. 2004;15: 1-8, http://dx.doi.org/10.1207/s15327965pli1501_01.

16. Heszen I. [Spiritual resources of man and somatic health]. In: Brzeziński J, Cierpiałkowska L, editors. [Health and disease. Problems of theory, diagnosis and practice]. Gdańsk: Gdańskie Wydawnictwo Psychologiczne; 2008. p. 96-118. Polish.

17. Heszen I. [Spirituality and its role in dealing with stress]. In: Suchocka L, Sztembis R, editors. [Man and work]. Lublin: Wydawnictwo KUL; 2010. p. 215-23. Polish.

18. Juczyński Z. [What gives a man the power to deal with suffering]. In: Suchocka L, Sztembis E, editors. [Man and work]. Lublin: Wydawnictwo KUL; 2010. p. 255-68. Polish.

19. Heszen-Niejodek I. [Spiritual dimension of man and health]. In: Juczyński Z, Ogińska-Bulik N, editors. [Personal and social resources facilitating the unit's health]. Łódź: Wydawnictwo UŁ; 2003. p. 33-47. Polish.

20. Watlington C, Murphy C. The roles of religion and spirituality among African American survivors of domestic violence. J Clin Psychol. 2006;62(7):837-57, http://dx.doi. org/10.1002/jclp.20268.

21. Krejci M, Thompson K, Simonich H, Crosby R, Donaldson A, Wonderlich S, et al. Sexual trauma, spirituality and psychopathology. J Child Sex Abuse. 2004;13(2):85-103, http://dx.doi.org/10.1300/J070v13n02_05.

22. Calhoun LG, Cann A, Tedeschi RG, McMillam J. A correlational test of the relationship between posttraumatic growth, religion and cognitive processing. J Trauma Stress. 2000;13(3):521-7, http://dx.doi.org/10.1023/ A:1007745627077.

23. Park CL, Fenster JR. Stress-related growth: Predictors of occurrence and correlates with psychological adjustment. J Soc Clin Psychol. 2004;23:195-215, http://dx.doi.org/ 10.1521/jscp.23.2.195.31019.

24. Shaw A, Joseph SP, Linley A. Religion, spirituality, and posttraumatic growth: A systematic review. Ment Health Relig Cult. 2005;8(1):1-11, http://dx.doi.org/10.1080/136746 7032000157981.

25. Prati G, Pietrantoni L. Optimism, social support and coping strategies contributing to posttraumatic growth:
A meta-analysis. J Loss Trauma. 2009;14(5):364-88, http://dx.doi.org/10.1080/15325020902724271.

26. Felcyn-Koczewska M, Ogińska-Bulik N. [Psychological factors supporting the occurrence of post-traumatic growth among people in mourning]. In: Ogińska-Bulik N, Miniszewska J, editors. [Health in man's life cycle]. Łódź: Wydawnictwo UŁ; 2012. p. 59-72. Polish.

27. Weiss D, Marmar C. The Impact of Event Scale - Revised. In: Wilson J, Keane T, editors. Assessing psychological trauma and PTSD: A handbook for practitioners. New York: Guilford Press; 1997. p. 399-411.

28. Ogińska-Bulik N, Juczyński Z. [Post-traumatic growth characteristics and measurement]. Psychiatry 2010;7(4): 129-42. Polish.

29. Heszen-Niejodek I, Gruszczyńska E. [Spiritual dimension of man, its significance in health psychology and its measurement]. Przegl Psychol. 2004;47(1):15-31. Polish.

30. Cieślak R. [Social support - problems and measurement techniques]. In: Sęk H, Cieślak R, editors. [Social support, stress and health]. Warszawa: Wydawnictwo Naukowe PWN; 2004. p. 106-22. Polish.

31. Ogińska-Bulik N. The role of personal and social resources in preventing adverse health outcomes in employees of uniformed professions. Int J Occup Med Environ Health. 2005;18(3):233-40.

32. McIntosh DN, Poulin MJ, Silver RC, Holman DA. The distinct roles of spirituality and religiosity in physical and mental health after collective trauma: A national longitudinal study in responses to the 9/11 attacks. J Behav Med. 2011;34(6):497-507, http://dx.doi.org/10.1007/ s10865-011-9331-y.

33. Wortmann J, Park C, Edmondson D. Trauma and PTSD: Does spiritual struggle mediate the link? Psychol Trauma. 2011;3(4):442-52, http://dx.doi.org/10.1037/a0021413.

34. Sheik AI. Posttraumatic growth in the context of heart disease. J Clin Psychol Med Set. 2004;11:265-73, http://dx.doi.org/10.1023/B:JOCS.0000045346.76242.73.

35. Widows MR, Jacobsen PB, Booth-Jones M, Fields KK. Predictors of posttraumatic growth following bone marrow transplantation for cancer. Health Psychol. 2005;24(3): 266-73, http://dx.doi.org/10.1037/0278-6133.24.3.266.

36. Cieslak R, Benight C, Schmidt N, Luszczynska A, Curtin E, Clark R, et al. Predicting posttraumatic growth among Hurricane Katrina survivors living with HIV: The role of self-efficacy, social support, and PTSD symptoms. Anxiety Stress Cop. 2009;22(4):449-63, http://dx.doi.org/10.1080/10615800802403815.

This work is licensed under a Creative Commons Attribution-NonCommercial 3.0 Poland License / Ten utwór jest dostępny na licencji Creative Commons Uznanie autorstwa - Użycie niekomercyjne 3.0 Polska - http://creativecommons.org/licenses/by-nc/3.0/pl. 